\title{
Variation in Susceptibility of Tanoak to the NA1 and EU1 Lineages of Phytophthora ramorum, the Cause of Sudden Oak Death
}

\author{
Kelsey L. Søndreli, ${ }^{1}$ Alan Kanaskie, ${ }^{2}$ Susanna Keriö, ${ }^{1}$ and Jared M. LeBoldus ${ }^{1,3, \dagger}$ \\ ${ }^{1}$ Department of Botany and Plant Pathology, Oregon State University, Corvallis, OR 97331-2902 \\ ${ }^{2}$ Oregon Department of Forestry, Private Forests Program, Forest Health Section, Salem, OR 97310 \\ ${ }^{3}$ Department of Forest Engineering, Resources, and Management, Oregon State University, Corvallis, OR 97331-5704
}

\begin{abstract}
Phytophthora ramorum, the cause of sudden oak death (SOD), kills tanoak (Notholithocarpus densiflorus) trees in southwestern Oregon and California. Two lineages of P. ramorum are now found in wildland forests of Oregon (NA1 and EU1). In addition to the management of SOD in forest ecosystems, disease resistance could be used as a way to mitigate the impact of $P$. ramorum. The objectives of this study were to (i) characterize the variability in resistance of $N$. densiflorus among families using lesion length; (ii) determine whether lineage, isolate, family, or their interactions significantly affect variation in lesion length; and

explained the majority of the variation in lesion length. There was no significant difference between the NA1 and EU1 lineages in terms of mean lesion length; however, there were differences among the six isolates. Lesions on seedlings collected from surviving trees at infested sites were smaller, on average, than lesions of seedlings collected from trees at noninfested sites $(P=0.0064)$. The results indicate that there is potential to establish a breeding program for tanoak resistance to SOD and that several isolates of $P$. ramorum should be used in an artificial inoculation assay.
\end{abstract} (iii) determine whether there are differences among isolates and among families in terms of lesion length. The parameters isolate nested within lineage (isolate[lineage]) and family $\times$ isolate(lineage) interaction
Keywords: clonal lineage, cultivar/resistance, disease management, EU1, forest, invasive disease, NA1, oomycetes, Phytophthora ramorum, trees
Tanoak (Notholithocarpus densiflorus (Hook. \& Arn.) P. S. Manos, C. H. Cannon, \& S. H. Oh) is the evolutionary link between chestnuts (Castanea) and oak (Quercus) species in the Western Hemisphere. This tree occupies the coastal ranges of southwestern Oregon and central California. Along with Douglas-fir (Pseudotsuga menziesii (Mirb.) Franco) and redwood (Sequoia sempervirens (Lamb. ex D. Don) Endl.), tanoak is one of the dominant species in the mixed-conifer forests of this region. In southern Oregon, tanoak occurs on approximately $4,050 \mathrm{~km}^{2}$ of forest land (Goheen et al. 2017). Tanoak trees can reach a height of $35 \mathrm{~m}$ and have thick, leathery evergreen leaves covered by large trichomes. This species regenerates abundantly from both acorns and stump sprouts following fire, windstorms, or forest harvest. Mature tanoak trees $(>76 \mathrm{~cm}$ in diameter at breast height $[\mathrm{DBH}]$ ) can produce large numbers of acorns ( $454 \mathrm{~kg}$ or approximately 110,000 acorns), with smaller trees (46 to $60 \mathrm{~cm} \mathrm{DBH)} \mathrm{producing}$ 3,900 to 4,600 acorns (Tappeiner et al. 1990). Abundant acorn production makes tanoak an important source of food for squirrels, deer, bears, and other mammals. Tanoak also has cultural significance for Native Americans in western Oregon and California, who use the acorns to produce flour and other foods (Bowcutt 2015). The population structure of tanoak in California and Oregon was characterized using nuclear and chloroplast DNA. Five main subpopulations including: southern Oregon, northern coastal California, central coastal California, the Klamath region, and the Sierra Nevada were identified (Nettel et al. 2009). This ecologically and culturally important species is

${ }^{\dagger}$ Corresponding author: J. M. LeBoldus; Jared.LeBoldus@oregonstate.edu

Funding: USDA-Forest Service, Pacific Southwest Research Station (Joint Venture Agreement, 16-JV-11272139-043) and the Bureau of Land Management.

*The $\boldsymbol{e}$-Xtra logo stands for "electronic extra" and indicates that four supplementary figures are published online.

The author(s) declare no conflict of interest.

Accepted for publication 11 June 2019.

(C) 2019 The American Phytopathological Society currently under threat of extirpation by the invasive plant pathogen, Phytophthora ramorum Werres, De Cock \& Man in't Veld, the cause of sudden oak death (SOD).

The SOD epidemic began in California in the mid 1990s (Rizzo et al. 2002) and the pathogen infects over 100 species in the coastal mixedevergreen forests of the Pacific Northwest. In Oregon, tanoak is the most susceptible tree species (Davidson et al. 2003; Rizzo and Garbelotto 2003) and inoculum from tanoak is the main driver of the disease epidemic (Hansen et al. 2008; Peterson et al. 2014). Infections begin in leaves and twigs in the upper crown which then develop abundant sporangia and zoospores. Canopy drip and stem flow eventually lead to the development of the most conspicuous symptom, bleeding cankers on the main stem. There are four genetic lineages of $P$. ramorum, each named for the continent on which it was first described and in the order of its discovery (NA1, NA2, EU1, and EU2). In California, only the NA1 lineage is found in wildland forests. However, in Oregon, both the NA1 (Goheen et al. 2002) and EU1 (Grünwald et al. 2016) lineages have been reported infecting and killing tanoak. Regardless of lineage or region, tanoak mortality has been reported to be as high as $100 \%$ in infested stands in the Big Sur region of California (Davis et al. 2010) and as high as $80 \%$ in plots in Marin County (McPherson et al. 2010). In Oregon, mortality of canopy tanoak increased from nearly 0 to $87 \%$ during the period of 2012 to 2016 in areas where infected tanoak was not actively being removed (Goheen et al. 2017). Although identification of the disease was too late for active management to be effective in California, SOD has been continuously managed in Oregon since its detection in 2001 (Goheen et al. 2002).

Well-organized and committed eradication efforts can slow the spread of a pathogen, providing time to develop management approaches that protect standing ecological, economic, or cultural resources (Hansen et al. 2008). The outbreak in Oregon likely began in 1998, with the NA1 lineage first detected in wildland forests near Brookings in Curry County in 2001 (Hansen et al. 2008). Since that time, there has been an ongoing effort to slow the spread of the pathogen by early detection and treatment, which consists of cutting and burning of infected and nearby tanoak. Depending on the resources available for treatments, a 100- to 300-m buffer surrounding the infected trees is removed as well as other susceptible tree and shrub species (Hansen et al. 2008; Peterson et al. 2014). 
The EU1 lineage was found in Oregon forests in 2015 and has since spread to tanoak and conifer seedlings (Grünwald et al. 2016; LeBoldus et al. 2018). The 2015 introduction has been linked to a nearby horticultural nursery that tested positive for EU1 in 2012. The Oregon Department of Forestry responded to the EU1 forest infestation by removing all tanoak trees within approximately $180 \mathrm{~m}$ of the infected trees. However, the pathogen has since spread to at least 30 new locations occupying approximately 400 ha of forestland. Due to the reportedly aggressive nature of the EU1 lineage (Denman et al. 2005; Elliott et al. 2011; Manter et al. 2010; O'Hanlon et al. 2017), the Oregon Department of Forestry and the United States Department of Agriculture (USDA) Forest Service have prioritized control and treatment of trees infected with this lineage of the pathogen.

Due to the rapid spread of $P$. ramorum in 2011 and 2012, the state quarantine was revised in 2012, establishing a "Generally Infested Area" (GIA) in which eradication treatments were no longer required. Currently, the GIA in Oregon covers $151 \mathrm{~km}^{2}$ (Goheen et al. 2017). This has left tanoak on the landscape within infested sites. Trees that have survived within the GIA may possess some form of disease resistance (Goheen et al. 2017). This has been reported in California, where individual trees in forests have survived for over 10 years at heavily infested sites (McPherson et al. 2010). Preliminary work evaluating tanoak resistance in California has demonstrated that resistance varied primarily within populations, with some variation among populations (Hayden et al. 2011). The same study also suggested that resistance was heritable (Hayden et al. 2011). As such, disease-resistant tanoak may be an additional tool used to mitigate the impacts of SOD in the coastal mixed-conifer forests of western North America.

Tree breeding programs have been successful at increasing individual resistance to invasive microbial pathogens and can provide longterm, restoration-focused management strategies for forest diseases (Sniezko 2006). For this approach to be successful, resistance must be variable, readily detectable, heritable, and durable. Artificial inoculations in controlled environments have been instrumental in the development of disease resistance breeding for other forest pathogens (Hansen et al. 2000; Kinloch 2003; Muchero et al. 2018). In order to develop a similar approach for SOD resistance in tanoak, the following study was conducted. The objectives of this study were to (i) characterize the variability in resistance of $N$. densiflorus among families using lesion length on wound-inoculated seedlings as the metric; (ii) determine whether $P$. ramorum lineage, isolate, $N$. densiflorus family, or their interactions significantly affect variation in lesion length; and (iii) determine whether there are differences among $P$. ramorum lineages, isolates, and $N$. densiflorus families in terms of lesion length.

\section{Materials and Methods}

Experiment 1: Year 2016. Tanoak acorns were collected in fall 2016 from 14 separate tanoak trees in wildland forests in Curry County, OR (acorns from a single tree $=$ family). Acorns were knocked out of trees using a pole pruner and collected from the ground. All collections were from single trees or multistemmed trees sharing a common root system. Acorns were sorted and counted after approximately 2 months of refrigerated storage (at approximately $4^{\circ} \mathrm{C}$ ). At the time of sorting, acorns with weevil exit holes, cracks, or other damage were discarded. Acorns were soaked for $48 \mathrm{~h}$ in $1 \% \mathrm{H}_{2} \mathrm{O}_{2}$, then for $24 \mathrm{~h}$ in aerated water. The acorns were placed in mesh bags in moist peat moss in a seed cooler at approximately
1 to $2^{\circ} \mathrm{C}$ for 5 weeks. They were then placed in germination boxes on blotter paper in a germination chamber at 19 and $17^{\circ} \mathrm{C}$ (day and night temperatures, respectively) with a 12 -h photoperiod. Germinated acorns were planted in Cone-tainers (Ray Leach SC10 Super Cone-tainers; Stuewe and Sons, Inc., Tangent, OR, U.S.A.) measuring $3.8 \mathrm{~cm}$ in diameter and $21 \mathrm{~cm}$ deep filled with growing medium. The growing medium consisted of peat/composted fir bark/perlite/ pumice (40:20:20:20), with Apex N-P $\mathrm{O}_{5}-\mathrm{K}_{2} \mathrm{O}$ (16:95:10) controlrelease fertilizer (5 to 6 months) (J. R. Simplot Company, Boise, ID, U.S.A.) added prior to sowing. Seedlings were grown in an open greenhouse (not climate controlled) for 1 year. Irrigation was carefully monitored to avoid overwatering. Slow-release fertilizer was supplemented once per week with a rotation of $\mathrm{N}-\mathrm{P}_{2} \mathrm{O}_{5}-\mathrm{K}_{2} \mathrm{O}$ at 17 : $5: 24$, 20:9:20, or 20:18:18, depending on weather conditions and physiological state of the seedlings. Three NA1 and three EU1 isolates of $P$. ramorum were collected from infected plant material (tanoak and Douglas-fir) in Curry County, OR as part of routine diagnostic testing for the Oregon Department of Forestry (Table 1). Isolations were made by plating symptomatic tissue on corn meal agar amended with $20 \mathrm{ppm}$ Delvocid (50\% natamycin), $200 \mathrm{ppm}$ Na-ampicillin, and 10 ppm rifamycin SV (CARP). Leaf or stem segments were aseptically removed from symptomatic tissue and $P h y$ tophthora spp. were isolated. The isolate was determined to be $P$. ramorum based on the presence of chlamydospores, characteristic hyphae, and sporangial morphology (Werres et al. 2001). DNA was extracted from mycelium from positive cultures and a portion of the cbel gene was amplified and sequenced using the CBEL5U and CBEL6L primers (Gagnon et al. 2014). The sequences of the isolates of unknown lineage were aligned to sequences of $\mathrm{cbel}$ for reference isolates of NA1, NA2, EU1, and EU2 using the Staden package in GAP v4.11.2. The alignments were used to assign each isolate to a lineage. Following lineage determination, isolates were stored as plugs in sterile water at room temperature. One week before inoculation, six isolates (three EU1 isolates and three NA1 isolates) were plated onto $6.7 \%$ V8 agar plates (Table 1).

In fall 2017, inoculations were conducted in a USDA Animal and Plant Health Inspection Service-certified growth chamber. The chamber had an 18-h photoperiod with F32T8 fluorescent bulbs (Phillips, Eindhoven, The Netherlands). The temperature regime was $20^{\circ} \mathrm{C}$ during the day and $18^{\circ} \mathrm{C}$ at night. The 1-year-old tanoak seedlings were inoculated with three different isolates from each lineage (NA1 and EU1) of $P$. ramorum (Table 1). Inoculations were conducted by removing a leaf at the midpoint of the tree, placing an agar plug colonized by $P$. ramorum mycelium over the leaf scar, and wrapping it with parafilm. This inoculation method has previously been used on Populus spp. to inoculate them with the fungal pathogen Sphaerulina musiva (LeBoldus et al. 2008; Long et al. 1986). One week after inoculation, the parafilm was removed and the length of each lesion was measured along with the height of the tree. Lesion extent was based on external discoloration of the stem. A control tree inoculated with a sterile $6.7 \%$ V8 agar plug was included for each family with more than 18 seedlings (seedlings grown from acorns collected from one tree $=$ family). If there were less than 18 seedlings in the family, then a control was not included. This was done to ensure at least three seedlings from each family were inoculated with each isolate (Table 2). After measuring the lesion lengths, 22 randomly selected lesions and all mockinoculated controls were plated on CARP. Plates were observed 1 week after plating to confirm $P$. ramorum infection.

Table 1. Phytophthora ramorum isolates used for inoculation ${ }^{\mathrm{a}}$

\begin{tabular}{|c|c|c|c|c|c|}
\hline $\begin{array}{l}\text { Isolate } \\
\text { number }\end{array}$ & $\begin{array}{l}\text { Isolate collection } \\
\text { name }\end{array}$ & Host & Date isolated & Location & Lineage \\
\hline 1 & 15106 & Notholithocarpus densiflorus & 25 May 2016 & Curry County, OR & NA1 \\
\hline 2 & 15115 & N. densiflorus & 9 June 2016 & Curry County, OR & NA1 \\
\hline 3 & 15275 & N. densiflorus & 10 August 2016 & Curry County, OR & NA1 \\
\hline 4 & 15279 & N. densiflorus & 11 August 2016 & Curry County, OR & EU1 \\
\hline 5 & 15423 & Pseudotsuga menziesii & 11 August 2016 & Curry County, OR & EU1 \\
\hline 6 & 15465 & N. densiflorus & 9 August 2016 & Curry County, OR & EU1 \\
\hline
\end{tabular}

${ }^{\text {a }}$ Shown for each isolate are the host it was isolated from, the date it was isolated, location of collection, and the lineage. 
Experiment 2: Year 2017. Tanoak acorns were collected in fall 2017 from 16 separate trees in Curry County, OR in the same manner as described above (Table 3). Acorns were collected from noninfested sites and from infested sites within the GIA. The same procedures as for experiment 1 were used to grow and inoculate the tanoak seedlings. In total, 11 randomly selected lesions and all controls were plated on CARP to confirm $P$. ramorum infection.

Data analysis for experiments 1 and 2. The experimental design was a completely randomized design. Each family was inoculated with each of the six isolates, randomly assigned to individual trees from that family (Tables 2 and 3). The mixed procedure in SAS 9.4 (SAS Institute, Cary, NC U.S.A.) was used to analyze the random effects of family, isolate nested within lineage (isolate[lineage]), the family $\times$ isolate(lineage) interaction, and the fixed effect of lineage on lesion length (Littell et al. 2006). Statistical significance was assessed at $\alpha=0.05$. A two-step model selection process was employed. Initially, to test the significance of random effects, a likelihood ratio $\chi^{2}$ test was used. The order of testing was determined based on the magnitude of the default $z$ test for random effects in SAS; the parameter with the largest $P$ value was tested first. In each subsequent model, nonsignificant parameters were removed. The significance of the fixed effects was evaluated using the $F$ test for the fixed effects in the mixed model output.
Following model selection, isolate(lineage) means were compared using the best linear unbiased predictors (BLUPs) (Littell et al. 2006). The LSMEANS statement was used with a Tukey's correction to test whether seedlings inoculated with the EU1 lineage have larger lesions than those inoculated with the NA1 lineage. Isolate BLUPs were each compared by estimating the confidence limit on the difference of the BLUPs. If the confidence limit overlapped zero then the BLUPs were similar. Differences and variation in lesion length between seedlings collected from infested and noninfested sites in experiment 2 were compared with two posthoc tests. The family BLUPs grouped by collection location were used. The first test was an $F$ test comparing the variance of seedlings collected from parents at infested sites and those collected from parents at noninfested sites. The second test was a $t$ test to compare the mean lesion length between families from the two groups.

\section{Results}

Experiment 1: Year 2016. Average germination rates of the acorns varied among families, ranging from 40 to $89 \%$ (Table 2). All P. ramorum-inoculated stems developed lesions within 7 days postinoculation. Overall, the lesion lengths ranged from 0.1 to $13.4 \mathrm{~cm}$, with many of the larger lesions girdling the stem and causing the seedlings to wilt. $P$. ramorum was isolated from 21 of 22 lesions. All controls were negative for $P$. ramorum and did not have visible lesions.

Table 2. Collection information for all the acorns collected in 2016 and used in experiment $1^{\text {a }}$

\begin{tabular}{|c|c|c|c|c|c|c|c|c|c|}
\hline Collection date & Latitude & Longitude & Location description & Zone & Family & $\operatorname{Acorns}(n)$ & $\operatorname{Germ}(\%)$ & $\begin{array}{c}\text { Total trees } \\
\text { used }\end{array}$ & Control \\
\hline 26 September 2016 & 42.68942 & -124.42850 & China Mtn Rd. at Humbug & Not infested & 1 & 120 & 79.2 & 30 & 1 \\
\hline 26 September 2016 & 42.68917 & -124.42734 & China Mtn Rd. at Humbug & Not infested & 2 & 90 & 58.9 & 28 & 1 \\
\hline 26 September 2016 & 42.68907 & -124.42496 & China Mtn Rd. at Humbug & Not infested & 3 & 300 & 76.3 & 122 & 2 \\
\hline 26 September 2016 & 42.68973 & -124.42522 & China Mtn Rd. at Humbug & Not infested & $4 \mathrm{~A}$ & 80 & 88.8 & 31 & 1 \\
\hline 26 September 2016 & 42.68967 & -124.42513 & China Mtn Rd. at Humbug & Not infested & $4 \mathrm{~B}$ & 300 & 89.3 & 209 & 2 \\
\hline 26 September 2016 & 42.68991 & -124.42538 & China Mtn Rd. at Humbug & Not infested & $4 \mathrm{C}$ & 300 & 67.0 & 145 & 2 \\
\hline 26 September 2016 & 42.69009 & -124.42568 & China Mtn Rd. at Humbug & Not infested & 4D & 80 & 62.5 & 17 & 0 \\
\hline 26 September 2016 & 42.69059 & -124.42598 & China Mtn Rd. at Humbug & Not infested & $4 \mathrm{E}$ & 460 & 75.0 & 236 & 4 \\
\hline 26 September 2016 & 42.69107 & -124.42486 & China Mtn Rd. at Humbug & Not infested & $4 \mathrm{~F}$ & 200 & 51.5 & 61 & 1 \\
\hline 26 September 2016 & 42.69258 & -124.42536 & China Mtn Rd. at Humbug & Not infested & $4 \mathrm{G}$ & 200 & 72.0 & 74 & 2 \\
\hline 7 October 2016 & 42.11720 & -124.21664 & Gardner Ridge Road & Not infested & GR1 & 130 & 40.0 & 24 & 1 \\
\hline 7 October 2016 & 42.11724 & -124.21640 & Gardner Ridge Road & Not infested & GR2 & 50 & 70.0 & 15 & 0 \\
\hline 7 October 2016 & 42.11687 & -124.21609 & Gardner Ridge Road & Not infested & Gr3 & 110 & 72.7 & 20 & 1 \\
\hline 7 October 2016 & 42.11620 & -124.21541 & Gardner Ridge Road & Not infested & G5 & 130 & 74.6 & 30 & 1 \\
\hline
\end{tabular}

a Included are the date of collection, the latitude and longitude (WGS1984) of each tree used for collection, the description of the location, whether it was collected from an infested site or not (Zone), the name of the family, the number of acorns collected from each tree, the percent germination (Germ) for each family, the total number of trees used in the experiment, and how many of those trees were used as controls.

Table 3. Collection information for acorns collected in 2017 and used in experiment $2^{\mathrm{a}}$

\begin{tabular}{|c|c|c|c|c|c|c|c|c|c|}
\hline Collection date & Latitude & Longitude & Location description & Zone & Family & Acorns (n) & $\operatorname{Germ}(\%)$ & $\begin{array}{c}\text { Total trees } \\
\text { used }\end{array}$ & Control \\
\hline 4 October 2017 & 42.01948 & -124.11471 & Winchuck & Not infested & 212 & 75 & 68.00 & 30 & 1 \\
\hline 4 October 2017 & 42.02699 & -124.11927 & Winchuck & Not infested & 213 & 55 & 78.18 & 30 & 1 \\
\hline 4 October 2017 & 42.02934 & -124.12435 & Winchuck & Not infested & 214 & 80 & 62.50 & 30 & 1 \\
\hline 4 October 2017 & 42.04556 & -124.13557 & Winchuck & Not infested & 217 & 53 & 66.04 & 30 & 1 \\
\hline 4 October 2017 & 42.05213 & -124.14036 & Winchuck & Not infested & 218 & 62 & 82.26 & 30 & 1 \\
\hline 4 October 2017 & 42.18797 & -124.34684 & China Creek Road & Infested & 226 & 63 & 60.32 & 30 & 1 \\
\hline 5 October 2017 & 42.32338 & -124.40427 & Meyers Creek Road & Infested & 230 & 66 & 56.06 & 30 & 1 \\
\hline 5 October 2017 & 42.32180 & -124.40452 & Meyers Creek Road & Infested & 231 & 78 & 48.72 & 30 & 1 \\
\hline 5 October 2017 & 42.31263 & -124.40625 & Meyers Creek Road & Infested & 232 & 79 & 48.10 & 30 & 1 \\
\hline 5 October 2017 & 42.68941 & -124.42618 & China Mountain Road & Not infested & 235 & 73 & 69.86 & 30 & 1 \\
\hline 5 October 2017 & 42.70147 & -124.42264 & China Mountain Road & Not infested & 238 & 71 & 77.46 & 30 & 1 \\
\hline 11 October 2017 & 42.73066 & -124.45914 & China Mountain Road & Not infested & 240 & 74 & 68.92 & 30 & 1 \\
\hline 11 October 2017 & 42.73040 & -124.45341 & China Mountain Road & Not infested & 242 & 74 & 85.14 & 42 & 1 \\
\hline 11 October 2017 & 42.72741 & -124.44696 & China Mountain Road & Not infested & 243 & 83 & 72.29 & 36 & 1 \\
\hline 11 October 2017 & 42.71959 & -124.43513 & China Mountain Road & Not infested & 245 & 126 & 51.59 & 42 & 1 \\
\hline 11 October 2017 & 42.71494 & -124.43204 & China Mountain Road & Not infested & 246 & 134 & 51.49 & 48 & 1 \\
\hline
\end{tabular}

a Included are the date of collection, the latitude and longitude (WGS1984) of each tree used for collection, the description of the location, whether it was collected from an infested site or not (Zone), the name of the family, the number of acorns collected from each tree, the percent germination (Germ) for each family, the total trees used in the experiment, and how many of those trees were used as controls. 
The final model included lineage $(P=0.1250)$, family $(P=$ $0.7518)$, isolate(lineage) $(P<0.0001)$, and the family $\times$ isolate (lineage) interaction $(P=0.0032)$. Isolate(lineage) explained the majority $(89.11 \%)$ of variation in lesion length $\left(\sigma^{2}=0.8258\right)$ while the family $x$ isolate(lineage) interaction $\left(\sigma^{2}=0.1009\right)$ explained $10.89 \%$ of the variation. There were significant differences among the six isolates in terms of lesion length, with the exception of isolates 5 and 6 , which were not significantly different (Fig. 1). The BLUPs for each familyisolate combination show an overall pattern of larger average lesion length for EU1 isolates (Supplementary Fig S1). However, there was no significant difference $(P=0.0625)$ in lesion length between the EU1 $(\overline{\mathrm{x}}=5.15 \mathrm{~cm})$ and NA1 $(\overline{\mathrm{x}}=3.69 \mathrm{~cm})$ lineages. Only 1 of the 14 families had a significant difference in lesion length between lineages $(P=0.0222)$. For all other families, there were no significant differences between the two lineages. The histograms depicting the pattern of variation in lesion length were similar for each family (Supplementary Fig S2).

Experiment 2: Year 2017. Average percent germination rates of the acorns varied among families, ranging from 49 to $85 \%$ (Table 3 ). All $P$. ramorum-inoculated stems developed lesions. Overall, the lesion lengths ranged from 0.2 to $10.8 \mathrm{~cm}$. Many of the stems were girdled and some seedlings wilted within 7 days postinoculation, similar to experiment 1. P. ramorum was isolated from 11 of 11 lesions and all controls were negative for $P$. ramorum and did not produce visible lesions.

The final model included lineage ( $P=0.1183)$, family $(P=0.2542)$, isolate(lineage) $(P=0.0047)$, and the family $\times$ isolate $($ lineage $)$ interaction $(P<0.0001)$. Family $\times$ isolate(lineage) interaction explained most of the variation $(69.96 \%)$ in the model $\left(\sigma^{2}=0.44066\right)$ while the isolate(lineage) explained $30.04 \%$ of the variation $\left(\sigma^{2}=0.1746\right)$. There were differences among the six isolates in terms of lesion length (Fig. 2). As in experiment 1 , the averages for each family $\times$ isolate combination show an overall pattern of larger average lesion length for EU1 isolates (Supplementary Fig S3).

Overall, there was no significant difference $(P=0.0592)$ in lesion lengths caused by the EU1 $(\overline{\mathrm{x}}=5.14 \mathrm{~cm})$ and NA1 $(\overline{\mathrm{x}}=4.38 \mathrm{~cm})$ lineages. In all, 3 of 16 families had significant differences between NA1 and EU1 (family 213, $P=0.0385$; family $218, P=0.0486$; and family $=226, P=0.0276$ ). The histograms depicting the overall pattern of variation were similar for each family (Supplementary Fig S4).

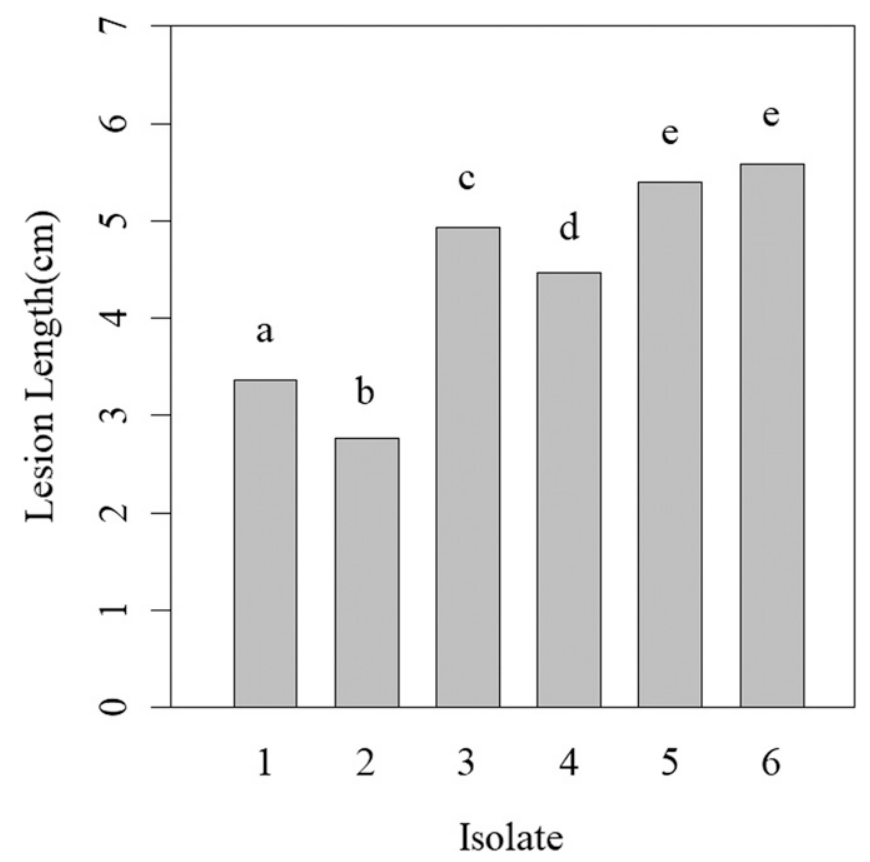

Fig. 1. Average lesion length for each Phytophthora ramorum NA1 (bars 1 to 3 ) and EU1 (bars 4 to 6 ) isolate for experiment 1. Different letters above each bar represent significant differences between the isolates.
The posthoc $F$ test of the variance of family BLUPs for lesion lengths indicated that the variation was higher $(P=0.0064)$ for the families collected from noninfested sites compared with the infested sites. The $t$ test also indicated that the lesions for the families collected from the noninfested $(\overline{\mathrm{x}}=4.6852)$ sites were larger $(P=$ $0.0357)$ than infested sites $(\overline{\mathrm{x}}=4.7864)$. For both experiments, the NA1 isolates tended to have more trees with smaller lesions than the EU1 isolates (Fig. 3).

\section{Discussion}

All tanoak families developed lesions in response to inoculation with all tested isolates. The lesions were macroscopically similar to previous studies (Rizzo and Garbelotto 2003). Our results indicate that the majority of the variation in lesion length in response to $P$. ramorum inoculation is explained by within- rather than amongfamily differences. Considering the short distance between the source trees for the acorns and the long pollen dispersal distances of forest trees (Savolainen et al. 2007), the lack of phenotypic differentiation in disease resistance between the tanoak families is expected. This pattern is typical of wind-pollinated trees when the environment does not impose a strong selection pressure on the phenotype and gene flow between populations is commonplace (Savolainen et al. 2007). Population level analysis of tanoak using microsatellites has indicated that barriers to gene flow among tanoak populations were absent, with $90 \%$ of molecular variance in nuclear markers explained by withinpopulation diversity (Nettel et al. 2009), supporting this hypothesis. This genetic structure is typical of a forest tree that reproduces predominantly by outcrossing (Ennos 1994; Nettel et al. 2009; Savolainen et al. 2007).

Families collected from infested sites appear to be more resistant and phenotypically more variable than families collected from noninfested sites. This was indicated by shorter lesions and smaller variation in lesion length for the families collected from infested sites. McPherson et al. (2010) reported a similar phenomenon, where individual trees had survived for over 10 years at heavily infested sites, indicating possible resistance to SOD. There are several possible explanations for this result. For example, not only are trees surviving at infested sites more resistant to the disease but they may also be selfpollinating at higher rates than in noninfested stands. Dodd et al. (2013a, b), when analyzing the population genetic structure of tanoak

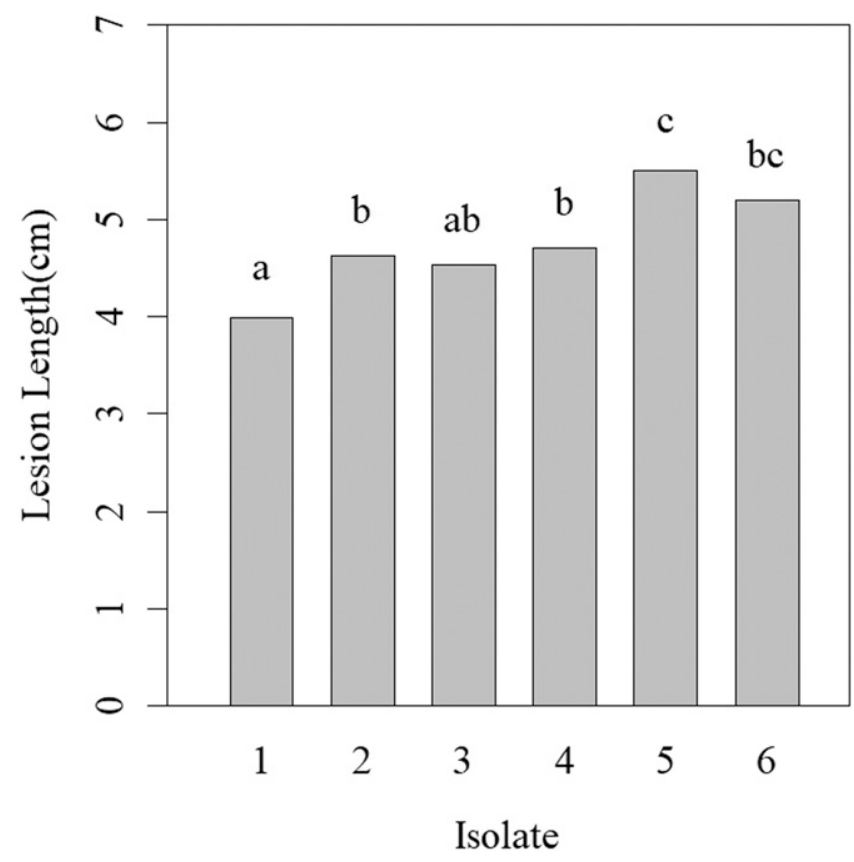

Fig. 2. Average lesion length for each Phytophthora ramorum NA1 (bars 1 to 3 ) and EU1 (bars 4 to 6 ) isolate for experiment 2. Different letters above each bar represent significant differences between the isolates. 
populations in California, indicated that acorns from a single tree may have multiple parents, including a subset which was produced by self-pollination. This could lead to more genetically uniform seedlings with higher levels of resistance to the disease. Alternatively, the surviving trees may be more likely to be pollinated by other surviving and putatively resistant trees, also resulting in more resistant progeny.

A successful tanoak resistance breeding program requires that resistance be variable, readily detectable, heritable, and durable. In this study, we have shown that there is evidence for the first two factors (detectable variation in resistance within the tanoak population) in response to $P$. ramorum. This is consistent with other studies where resistance has a role in tanoak- $P$. ramorum disease dynamics (Hayden et al. 2011, 2013). In fact, genetic-based variability in resistance to $P$. ramorum has been detected in other species affected by this disease. In California, coast live oak (Quercus agricolia Née) varies in its response to inoculation with $P$. ramorum (Dodd et al. 2005, 2008). The third criterion for the development of a successful disease resistance breeding program is that resistance should be heritable. Previous studies have estimated the narrow-sense heritability of stem and leaf lesions to be 0.10 and 0.08 to 0.11 , respectively (Hayden et al. 2013), and the broad-sense heritability for lesion area to be 0.27 (Hayden et al. 2011). This degree of heritability is typical for traits not under strong selective pressure. However, in the case of a naive host and an invasive pathogen, low heritability reflects lack of coevolution and low frequency of resistance associated genes in the host population (Ennos 2015). The durability of resistance, the fourth aspect of a successful disease resistance breeding program, is unknown. However, $P$. ramorum is clonal and has not been reported to reproduce sexually. This greatly reduces the likelihood of recombination among individuals and the risk of new, more aggressive isolates from appearing and spreading on the landscape. It should be noted that mitotic recombination has been reported as a mechanism for generating genetic variation within a clonal lineage for $P$. ramorum (Dale et al. 2019) and for P. cinnamomi (Dobrowolski et al. 2003). It has been suggested that mitotic recombination might purge disadvantageous mutations without disrupting the genotypic makeup of the invasive clonal lineages (Dobrowolski et al. 2003). The biological significance of this finding is still unclear for wildland forests.

To date, efforts to evaluate tanoak resistance to $P$. ramorum have used a single isolate in controlled inoculation experiments (Hayden et al. 2011, 2013, 2014) or relied on natural infection (Cobb et al. 2019; Hayden et al. 2011, 2013). The significant family $\times$ isolate(lineage) interaction indicates that more than one isolate may be necessary for artificial inoculations. This interaction indicates that lesion length is dependent on the specific family $\times$ isolate combination being tested. For example, the most aggressive isolate infecting one family may not be the most aggressive isolate when a different family is inoculated. A second piece of evidence suggesting the importance of isolate selection in disease resistance screening can be seen in a comparison of the frequency distributions of lesion length grouped by isolate (Fig. 3). Most isolates appear to cause a similar range of disease severities, with differences only in terms of the number of individuals in the different categories (Fig. 3). Less aggressive isolates have more individuals in the lower lesion-length categories than the more aggressive isolates. If a specific isolate's aggressiveness has not been well characterized prior to its use in disease resistance screening, it may be possible to overestimate the level of resistance of an individual or tanoak family. In general, these results indicate that using several well-characterized isolates, perhaps as a bulked zoospore
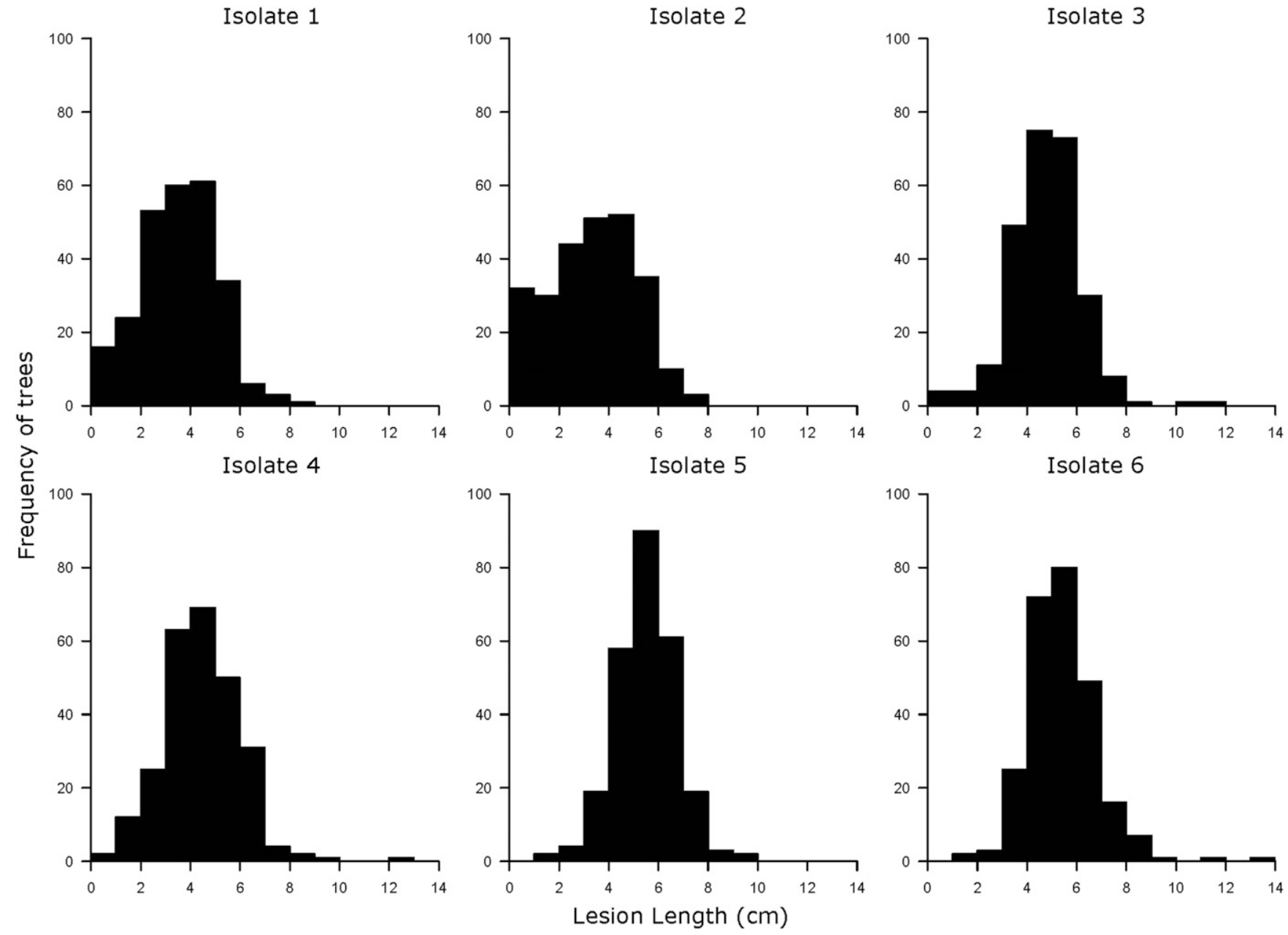

Fig. 3. Histograms of lesion length for each isolate (NA1 = top and EU1 = bottom) for both experiments combined. 
suspension, would be the best approach to screen tanoak seedlings for resistance.

We hypothesized that the EU1 lineage of $P$. ramorum would be more aggressive, in terms of lesion length, when infecting tanoak than the NA1 lineage. This hypothesis was based on experimental evidence from rhododendron in the literature (Denman et al. 2005; Elliot et al. 2011; Manter et al. 2010; O'Hanlon et al. 2017). However, with the exception of 4 of 30 families tested, there were no significant differences in lesion length between the EU1- and NA1-inoculated tanoak families. Given the variability within a single family and the significant family $x$ isolate(lineage) interaction in both experiments, this is not unexpected. Tanoak trees are predominantly outcrossing, with many individuals contributing pollen to the acorns collected from a single tree. Because disease resistance to $P$. ramorum in tanoak is thought to be a quantitative trait, the number of individuals from a single tree are highly variable in many phenotypic traits, not just their response to the pathogen. Another possible explanation could be host-induced phenotypic diversification that has been seen in previous studies (Elliott et al. 2018; Kasuga et al. 2012). These studies suggest that the occurrence of the nonwild-type NA1 isolates have made this lineage less aggressive (Elliott et al. 2018; Kasuga et al. 2012). However, the three NA1 isolates used in this study were wild-type isolates.

To our knowledge, the results described here are the first evaluating the variation in resistance to multiple isolates of the EU1 and NA1 lineages of $P$. ramorum for tanoak seedlings collected in Oregon. This work could be further expanded to include the EU2 lineage which has recently emerged in the United Kingdom in order to evaluate the risk to tanoak if this lineage were introduced to Oregon and California mixed-conifer forests. The results are broadly consistent with previous reports, where either artificial inoculations or natural infections have been used. Resistance is variable, detectable, and appears to be heritable. Although a source of resistance in tanoak to $P$. ramorum remains elusive, collections from tanoak that persist following severe infestation remain the most promising source of putatively resistant trees.

\section{Acknowledgments}

We thank the staff at USDA Forest Service Dorena Genetic Resource Center for their help in growing the tanoak; Richard Sniezko with help coordinating funding, logistics, and tanoak propagation; E. Hansen, P. Reeser, and W. Sutton for providing the isolates for this study; and two anonymous reviewers.

\section{Literature Cited}

Bowcutt, F. 2015. The Tanoak Tree: An Environmental History of a Pacific Coast Hardwood. University of Washington Press, Seattle, WA, U.S.A.

Cobb, R., Ross, N., Hayden, K. J., Eyre, C. A., Dodd, R. S., Frankel, S., Garbelotto, M., and Rizzo, D. M. 2019. Promise and pitfalls of endemic resistance for cultural resources threatened by Phytophthora ramorum. Phytopathology 109:760-769.

Dale, A. L., Feau, N., Everhart, S. E., Dhillon, B., Wong, B., Sheppard, J., Bilodeau, G. J., Brar, A., Tabima, J. F., Shen, D., Brasier, C. M., Tyler, B. M., Grünwald, N. J., and Hamelin, R. C. 2019. Mitotic recombination and rapid genome evolution in the invasive forest pathogen Phytophthora ramorum. MBio 10:e02452-18.

Davidson, J. M., Werres, S., Garbelotto, M., Hansen, E. M., and Rizzo, D. M. 2003. Sudden oak death and associated diseases caused by Phytophthora ramorum. Plant Health Prog. 4 doi.org/10.1094/PHP-2003-0707-01-DG

Davis, F. W., Borchert, M., Meentemeyer, R. K., Flint, A., and Rizzo, D. M. 2010. Pre-impact forest composition and ongoing tree mortality associated with sudden oak death in the Big Sur region, California. For. Ecol. Manage. 259: 2342-2354.

Denman, S., Kirk, S. A., Brasier, C. M., and Webber, J. F. 2005. In vitro leaf inoculation studies as an indication of tree foliage susceptibility to Phytophthora ramorum in the UK. Plant Pathol. 54:512-521.

DiLeo, M. V., Bostock, R. M., and Rizzo, D. M. 2014. Microclimate impacts survival and prevalence of Phytophthora ramorum in Umbellularia californica, a key reservoir host of sudden oak death in northern California forests. PLoS One 9:e98195.

Dobrowolski, M. P., Tommerup, I. C., Shearer, B. L., and O'Brien, P. A. 2003. Three clonal lineages of Phytophthora cinnamomi in Australia revealed by microsatellites. Phytopathology 93:695-704.

Dodd, R. S., Afzal-Rafii, Z., and Mayer, W. 2008. Molecular markers show how pollen and seed dispersal affect population genetic structure in coast live oak (Quercus agrifolia Née). Pages 485-495 in: Proc. Sixth Symp. Oak Woodlands:
Today's Challenges, Tomorrow's Opportunities. U. S. Dep. Agric. Gen. Tech. Rep. PSWGTR-217.

Dodd, R. S., Hüberli, D., Douhovnikoff, V., Harnik, T. Y., Afzal-Rafii, Z., and Garbelotto, M. 2005. Is variation in susceptibility to Phytophthora ramorum correlated with population genetic structure in coast live oak (Quercus agrifolia)? New Phytol. 165:203-214.

Dodd, R. S., Mayer, W., Nettel, A., and Afzal-Rafii, Z. 2013a. Clonal growth and fine-scale genetic structure in tanoak (Notholithocarpus densiflorus: Fagaceae) J. Hered. 104:105-114.

Dodd, R. S., Nettel, A., Wright, J. W., and Afzal-Rafii, Z. 2013b. Genetic structure of Notholithocarpus densiflorus (Fagaceae) from the species to the local scale: A review of our knowledge for conservation and replanting. Madrono 60: 130-138.

Elliott, M., Sumampong, G., Varga, A., Shamoun, S. F., James, D., Masri, S., and Grünwald, N. J. 2011. Phenotypic differences among three clonal lineages of Phytophthora ramorum. For. Pathol. 41:7-14.

Elliott, M., Yuzon, J., Tripathy, S., Bui, M., Chastagner, G. A., Coats, K., Rizzo, D. M., Garbelotto, M., and Kasuga, T. 2018. Characterization of phenotypic variation and genome aberrations observed among Phytophthora ramorum isolates from diverse hosts. BMC Genomics 19:320.

Ennos, R. 1994. Estimating the relative rates of pollen and seed migration among plant populations. Heredity 72:250-259.

Ennos, R. A. 2015. Resilience of forests to pathogens: An evolutionary ecology perspective. For. Int. J. For. Res. 88:41-52.

Gagnon, M. C., Bergeron, M. J., Hamelin, R. C., Grünwald, N. J., and Bilodeau, G. J. 2014. Real-time PCR assay to distinguish Phytophthora ramorum lineages using the cellulose binding elicitor lectin (CBEL) locus. Can. J. Plant Pathol. 36: 367-376.

Goheen, E. M., Hansen, E. M., Kanaskie, A., McWilliams, M. G., Osterbauer, N., and Sutton, W. 2002. Sudden oak death caused by Phytophthora ramorum in Oregon. Plant Dis. 86:441.

Goheen, E. M., Kanaskie, A., Navarro, S., and Hansen, E. 2017. Sudden oak death management in Oregon tanoak forests. For. Phytophthoras 7:45-53.

Grünwald, N. J., Larsen, M. M., Kamvar, Z. N., Reeser, P. W., Kanaskie, A., Laine, J., and Wiese, R. 2016. First report of the EU1 clonal lineage of Phytophthora ramorum on tanoak in an Oregon forest. Plant Dis. 100: 1024.

Hansen, E. M., Goheen, D. J., Jules, E. S., and Ullian, B. 2000. Managing PortOrford-cedar and the introduced pathogen Phytophthora lateralis. Plant Dis. 84:4-14.

Hansen, E. M., Kanaskie, A., Prospero, S., McWilliams, M., Goheen, E. M., Osterbauer, N., Reeser, P., and Sutton, W. 2008. Epidemiology of Phytophthora ramorum in Oregon tanoak forests. Can. J. For. Res. 38:1133-1143.

Hayden, K. J., Garbelotto, M., Dodd, R., and Wright, J. W. 2013. Scaling up from greenhouse resistance to fitness in the field for a host of an emerging forest disease. Evol. Appl. 6:970-982.

Hayden, K. J., Garbelotto, M., Knaus, B. J., Cronn, R. C., Rai, H., and Wright J. W. 2014. Dual RNA-seq of the plant pathogen Phytophthora ramorum and its tanoak host. Tree Genet. Genomes 10:489-502.

Hayden, K. J., Nettel, A., Dodd, R. S., and Garbelotto, M. 2011. Will all the trees fall? Variable resistance to an introduced forest disease in a highly susceptible host. For. Ecol. Manage. 261:1781-1791.

Kasuga, T., Kozanitas, M., Bui, M., Hüberli, D., Rizzo, D. M., and Garbelotto, M. 2012. Phenotypic diversification is associated with host-induced transposon derepression in the sudden oak death pathogen Phytophthora ramorum. PLoS One 7:e34728.

Kinloch, B. B., Jr. 2003. White pine blister rust in North America: Past and prognosis. Phytopathology 93:1044-1047.

LeBoldus, J. M., Blenis, P. V., and Thomas, B. R. 2008. Clone by isolate interaction in the hybrid poplar-Septoria musiva pathosystem. Can. J. For. Res. 38:1888-1896.

LeBoldus, J. M., Sondreli, K. L., Sutton, W., Reeser, P. W., Kanaskie, A., Navarro, S., and Grünwald, N. J. 2018. First report of Phytophthora ramorum lineage EU1 infecting Douglas-fir and grand fir in Oregon. Plant Dis. 102:455.

Littell, R. C., Milliken, G. A., Stroup, W. W., Wolfinger, R. D., and Schabenberger, O. 2006. SAS ${ }^{\circledR}$ for Mixed Models, 2nd ed. SAS Institute Inc., Cary, NC, U.S.A.

Long, R., Bowersox, T. W., and Merrill, W. 1986. Artificial inoculation of Populus hybrids with Septoria musiva. Can. J. For. Res. 16:405-407.

Manter, D. K., Kolodny, E. H., Hansen, E. M., and Parke, J. L. 2010. Virulence, sporulation, and elicitin production in three clonal lineages of Phytophthora ramorum. Physiol. Mol. Plant Pathol. 74:317-322.

McPherson, B. A., Mori, S. R., Wood, D. L., Kelly, M., Storer, A. J., Svihra, P., and Standiford, R. B. 2010. Responses of oaks and tanoaks to the sudden oak death pathogen after 8 y of monitoring in two coastal California forests. For. Ecol. Manage. 259:2248-2255.

Muchero, W., Sondreli, K. L., Chen, J.-G., Urbanowicz, B. R., Zhang, J., Singan, V., Yang, Y., Brueggeman, R. S., Franco-Coronado, J., Abraham, N., Yang, J.-Y., Moremen, K. W., Weisberg, A. J., Chang, J. H., Lindquist, E., Berry, K., Ranjan, P., Jawdy, S., Schmutz, J., Tuskan, G. A., and LeBoldus, J. M 2018. Association mapping, transcriptomics, and transient expression identify candidate genes mediating plant-pathogen interactions in a tree. Proc. Natl Acad. Sci. U.S.A. 115:11573-11578. 
Nettel, A., Dodd, R. S., and Afzal-Rafii, Z. 2009. Genetic diversity, structure, and demographic change in tanoak, Lithocarpus densiflorus (Fagaceae), the most susceptible species to sudden oak death in California. Am. J. Bot. 96:2224-2233.

O'Hanlon, R., Choiseul, J., Grogan, H., and Brennan, J. M. 2017. In-vitro characterisation of the four lineages of Phytophthora ramorum. Eur. J. Plant Pathol. 147:517-525.

Peterson, E., Hansen, E., and Kanaskie, A. 2014. Spatial relationship between Phytophthora ramorum and roads or streams in Oregon tanoak forests. For. Ecol. Manage. 312:216-224.

Rizzo, D. M., and Garbelotto, M. 2003. Sudden oak death: Endangering California and Oregon forest ecosystems. Front. Ecol. Environ. 1:197-204.

Rizzo, D. M., Garbelotto, M., Davidson, J. M., Slaughter, G. W., and Koike, S. T. 2002. Phytophthora ramorum as the cause of extensive mortality of Quercus spp. and Lithocarpus densiflorus in California. Plant Dis. 86:205-214.
Savolainen, O., Pyhäjärvi, T., and Knürr, T. 2007. Gene flow and local adaptation in trees. Annu. Rev. Ecol. Evol. Syst. 38:595-619.

Sniezko, R. A. 2006. Resistance breeding against nonnative pathogens in forest trees-Current successes in North America. Can. J. Plant Pathol. 28:S270S279.

Tappeiner, J. C., McDonald, P. M., and Roy, D. F. 1990. Lithocarpus densiflorus (Hook. \& Arn.) Rehd. Tanoak. Pages 417-425 in Silvics of North America, Vol. 2, Hardwoods. R. M. Burns and B. H. Haonkala, tech coords. Agriculture Handbook 654. United States Department of Agriculture Forest Service, Washington, DC, U.S.A.

Werres, S., Marwitz, R., Man In't Veld, W. A., De Cock, A. W. A. M., Bonants, P. J. M., De Weerdt, M., Themann, K., Ilieva, E., and Baayen, R. P. 2001. Phytophthora ramorum sp. nov., a new pathogen on Rhododendron and Viburnum. Mycol. Res. 105:1155-1165. 